\title{
ANALISIS METODE EUCS DAN HOT-FIT DALAM MENGEVALUASI PENERAPAN SISTEM INFORMASI MANAJEMEN KEPEGAWAIAN (SIMPEG)
}

\author{
Novianti Puspitasari ${ }^{1}$, Willyardo Tampubolon ${ }^{2}$, Medi Taruk $^{3}$ \\ ${ }_{1,2,3}$ Universitas Mulawarman
}

Article Info:

Dikirim: 19 Maret 2021

Direvisi: 28 Juni 2021

Diterima: 29 Juni 2021

Tersedia Online: 30 Juni 2021

Penulis Korespondensi:

Novianti Puspitasari

Universitas Mulawarman,

Samarinda, Indonesia

Email: novia.ftik.unmul@gmail.com

\begin{abstract}
Abstrak: Sistem Informasi Manajemen Kepegawaian (SIMPEG) merupakan bagian di sebuah organisasi yang sangat penting untuk diperhatikan demi keberhasilan pelayanan administrasi kepegawaian. Evaluasi terhadap penggunaan SIMPEG dalam mendukung pelayanan administrasi kepegawaian perlu dilakukan agar sistem dapat terus digunakan dan sebagai bahan rekomendasi untuk perbaikan sistem di masa yang akan datang. Penelitian ini bertujuan untuk mengetahui tanggapan dari pengguna SIMPEG dan melihat hasil dari evaluasi penerapan SIMPEG menggunakan metode Human Organization Technology (HOT-Fit) dan End User Computing Satisfaction (EUCS). Metode HOT-Fit merupakan metode yang meletakkan elemen penting dalam sistem informasi yaitu Human, Organization, Technology dan kesesuaian hubungan diantaranya. Lebih lanjut, metode EUCS digunakan untuk memberikan penilaian kepuasan pengguna terhadap kualitas sistem. Hasil penelitian menunjukan bahwa kesembilan hipotesis diterima dan memiliki pengaruh yang positif. Nilai hipotesis tertinggi adalah pengaruh Human (manusia) terhadap Technology (teknologi), dan nilai hipotesis paling rendah dimiliki oleh kesesuaian hubungan antara variabel HOT (Human, Organization, and Technology) terhadap nets benefit (manfaat).
\end{abstract}

Kata kunci: evaluasi; HOT-Fit; sistem; pegawai; EUCS.

\begin{abstract}
The Personnel Management Information System (SIMPEG) is an essential part of an organization to be considered for the success of personnel administration services. An evaluation of the use of SIMPEG in supporting personnel administration services needs to do so that the system can continue to use and recommend system improvements in the future. This study aims to determine the responses of SIMPEG users and see the results of evaluating the implementation of SIMPEG using the Human Organization Technology (HOTFit) and End User Computing Satisfaction (EUCS) methods. The HOT-Fit method is a method that puts essential elements in information systems, namely Human, Organization, Technology, and the suitability of the relationship between them. Furthermore, the EUCS method uses to assess user satisfaction with the quality of the system. The results showed that the nine hypotheses were accepted and had a positive influence. The highest hypothesis value is the influence of Humans on Technology, and the lowest hypothesis value is own by the suitability of the relationship between the HOT (Human, Organization, and Technology) variables on net benefit.
\end{abstract}

Keywords: evaluation; HOT-Fit; system; employee; EUCS. 


\section{PENDAHULUAN}

Sistem informasi adalah bagian penting dalam penggunaan teknologi informasi. Sistem informasi dapat didefinisikan sebagai serangkaian prosedur formal di mana data dikumpulkan, diproses menjadi informasi, dan didistribusikan kepada para pemakai [1]. Sistem informasi dikembangkan untuk membantu pengguna (user) dalam melakukan tugasnya. Pemanfaatan sistem informasi dalam suatu organisasi dapat memberikan kemudahan bagi organisasi tersebut dalam menjalankan usahanya, terutama dalam memproses informasi. Organisasi memerlukan sistem informasi yang terintegrasi yang disebut sebagai sistem informasi manajemen untuk mengolah dan memproses berbagai macam informasi yang ada didalam organisasi. Sistem Informasi Manajemen Kepegawaian (SIMPEG) dirancang sebagai alat untuk membantu pihak organisasi dalam pengurusan administrasi kepegawaian mulai dari pemusatan data (integration data) dan penyimpanan data secara terkomputerisasi hingga menangani berbagai jenis laporan yang berhubungan dengan data kepegawaian sehingga memudahkan para pegawai dalam mengurus administrasi kepegawaian dan menyediakan informasi data pegawai secara cepat, tepat, akuntabel, dan up to date [2]. SIMPEG telah digunakan oleh Badan Kepegawaian, Pendidikan dan Pelatihan Daerah (BKPPD) Kota Samarinda sejak tahun 2009. Namun, evaluasi terkait penggunaan SIMPEG di organisasi belum pernah dilakukan. Evaluasi terhadap penerapan sistem informasi yang digunakan di suatu organisasi memang telah menjadi sebuah fenomena yang kompleks namun sangat penting untuk dilakukan [3]-[5]. Evaluasi diperlukan untuk melihat faktor-faktor yang mendukung keberhasilan penerapan dari SIMPEG dalam rangka mendukung dan meningkatkan pelayanan administrasi kepegawaian secara maksimal serta mengukur kondisi atau menggali (menemukan) semua atribut dari sistem untuk mendefiniskan seberapa baik sistem dapat beroperasi pada organisasi yang menerapkannya dan sebagai bahan rekomendasi untuk memperbaiki sistem dimasa mendatang [6], [7].

Metode evaluasi penerapan sistem informasi yang dapat digunakan diantaranya adalah End User Computing Satisfaction (EUCS), dan Human Organization Technology (HOT-Fit). Metode EUCS telah diterapkan dalam berbagai penelitian untuk mengevaluasi kepuasaan pengguna seperti aplikasi Tapp Market yang merupakan aplikasi online shop dengan hasil penelitian menunjukkan bahwa pengguna aplikasi merasa puas terhadap konten yang ditampilkan oleh aplikasi, namun pengguna masih merasa tidak puas terhadap ketepatan waktu sistem dalam menyediakan data dan informasi yang diminta oleh pengguna [8]. Selain itu metode evaluasi EUCS juga dilakukan terhadap e-learning [9], sistem perpustakaan [10] dan sistem yang lain [1], [11]-[13]. Metode EUCS mampu mengukur tingkat kepuasan pengguna terhadap suatu sistem dengan membandingkan antara harapan dan kenyataan dari sebuah sistem informasi yang menekankan pada kepuasan (satisfaction) pengguna, dengan cara menganalisa sistem berdasarkan isi (konten), keakuratan, tampilan, kemudahan pengguna dan ketepatan waktu [1], [14]. Metode EUCS lebih menekankan kepuasan pengguna berdasarkan pengalaman pengguna terkait dengan penggunaan sistem informasi. Model evaluasi EUCS digunakan untuk mengukur tingkat kepuasan dari pengguna sistem informasi yang dikembangkan oleh Doll \& Torkzadeh [12]. Komponen EUCS terdiri dari Content (Konten), Accuracy (Keakuratan), Format (Tampilan), Ease of Use (Kemudahan Penggunaan), dan Timeliness (Ketepatan). Variabel content digunakan untuk mengukur keberhasilan sistem dalam menghasilkan informasi yang sesuai (tepat) dengan kebutuhan pengguna. Variabel accuracy dapat mengukur kepuasan pengguna berdasarkan keakuratan data yang dihasilkan oleh sistem pada saat sistem menerima input kemudian mengolahnya menjadi informasi. Variabel format mengukur kepuasan pengguna berdasarkan estetika dan tampilan yang dihasilkan oleh antar muka sistem, format dari laporan yang dihasilkan oleh sistem, atau informasi yang dihasilkan oleh sistem. Variabel Ease of Use mengukur kepuasan pengguna dilihat dari sudut pandang kemudahan pengguna (user-friendly) dalam menggunakan sistem. Variabel Timeliness digunakan untuk mengukur kepuasan pengguna dalam menyajikan atau menyediakan data dan informasi yang dibutuhkan oleh pengguna berdasarkan ketepatan waktu sistem [15].

Lebih lanjut, metode HOT-Fit merupakan metode evaluasi yang tidak hanya mengukur tingkat kepuasan pengguna terhadap penerapan sistem informasi, tetapi juga meletakkan komponen penting dalam penggunaan sistem yaitu Human (Manusia), Organization (Organisasi), Technology (Teknologi) dan kesesuaian hubungan diantaranya sebagai faktor keberhasilan dalam penerapan sistem informasi [16]. Metode HOT-Fit adalah sebuah kerangka baru yang dikembangkan oleh Yusof M.M., Paul RJ dan Stregioulas, L.K yang dapat digunakan untuk mengevaluasi sistem informasi berdasarkan model DeLone McLean. Komponen Human menilai sistem informasi dari sisi penggunaan sistem (system use) pada frekuensi dan luasnya fungsi serta penyelidikan sistem informasi. System use berhubungan erat dengan siapa yang menggunakan (who use it), tingkat penggunanya (level of user), pelatihan, pengetahuan, harapan serta sikap menerima dan menolak sistem. Komponen Organization menilai sistem dari aspek struktur organisasi dan lingkungan organisasi. Lebih lanjut, komponen teknologi terdiri atas kualitas sistem (sistem quality), kualitas informasi (information quality) dan kualitas layanan (service quality) [17]. Berdasarkan latar belakang tersebut, maka metode EUCS dan HOT-Fit sangat sesuai untuk melakukan evaluasi terhadap SIMPEG dengan tujuan untuk mengetahui tingkat penerimaan pengguna terhadap SIMPEG dan menjadi bahan rekomendasi untuk proses pengembangan SIMPEG ke depannya.

\section{METODOLOGI PENELITIAN}

Bab ini membahas tentang objek penelitian, instrument penelitian, dan model hipotesis yang dibentuk dalam penelitian ini. 


\subsection{Objek Penelitian}

Objek penelitian adalah pegawai di Badan Kepegawaian, Pendidikan dan Pelatihan Daerah (BKPPD) Kota Samarinda yang menggunakan SIMPEG sebanyak 63 pegawai. Jumlah pegawai tersebut ditentukan menggunakan teknik penarikan sampel yaitu simple random sampling berdasarkan perhitungan rumus Slovin.

$$
\boldsymbol{n}=\frac{N}{1+\left(N * e^{2}\right)}
$$

Dari persamaan (1), $n$ adalah jumlah sampel minimal, nilai $N$ adalah populasi, sedangkan $e$ adalah error tolerance, yang dimaksudkan dari error tolerance adalah besar sampel minimal berdasarkan tingkat kesalahan atau batas toleransi kesalahan sebesar $5 \%$.

\subsection{Instrumen Penelitian}

Instrumen yang digunakan dalam penelitian ini adalah kuesioner yang disebarkan kepada responden, dimana didalamnya berisi daftar pertanyaan. Penyusunan kuesioner disesuaikan dengan kondisi di lapangan. Skala pengukuran pernyataan yang ada pada kuesioner dalam penelitian ini mengacu pada Skala Likert (Likert Scale). Skala likert merupakan metode yang digunakan untuk mengukur respon (sikap) seseorang terhadap obyek, subyek atau kejadian tertentu dengan pernyataan setuju atau ketidaksetujuannya [11]. Responden diminta untuk memberikan respon terhadap setiap pertanyaan didalam kuesioner berdasarkan skala likert yang digunakan dengan memilih salah satu jawaban dari pilihan yang tersedia. Skala likert penelitian ini terdiri dari empat klasifikasi jawaban yang diberikan dengan kemungkinan pemberian bobot yang terlihat pada Tabel 1 .

Tabel 1. Skala Likert

\begin{tabular}{ccc}
\hline Jawaban & Alternatif & Bobot \\
\hline Tidak Setuju & TS & 4 \\
Kurang Setuju & KS & 3 \\
Setuju & S & 2 \\
Sangat Setuju & SS & 1 \\
\hline
\end{tabular}

Kuesioner berisi setiap variabel dari EUCS dan HOT-Fit yang terdiri atas 3-4 pertanyaan. Kuisioner terbagi atas variabel Content (X1), Accuracy (X2), Format (X3), Timeliness (X4), Ease of use (X5), User Satisfaction (Y1), System Quality (X6), Service Quality (X7), Information Quality (X8), Structure Organization (X9), Sistem use (X10), User Satisfaction (X11), Human (X12), Organization (X13), Technology (X14), dan Net Benefits (Y2). Tabel 2 menampilkan detail variabel dengan indikator konstruk untuk mengukur variabel-variabel tersebut.

Tabel 2. Detail variabel EUCS dan HOT-Fit

\begin{tabular}{cll}
\hline No & \multicolumn{1}{c}{ Indikator Konstruk } & Variabel EUCS \\
\hline 1 & Isi dari informasi SIMPEG sesuai kebutuhan pegawai & \\
2 & SIMPEG menampilkan isi informasi yang mudah dipahami & Content $\left(\mathrm{X}_{1}\right)$ \\
3 & SIMPEG menampilkan isi informasi yang mudah dan lengkap & \\
4 & Isi dari informasi di SIMPEG sangat jelas & \multirow{2}{*}{ Accuracy $\left(\mathrm{X}_{2}\right)$} \\
\hline 5 & SIMPEG sudah memberikan informasi yang akurat dan benar \\
6 & SIMPEG selalu selalu menampilkan halaman web yang sesuai bila & \\
\hline 7 & pengguna mengklik setiap link di SIMPEG & \multirow{2}{*}{ Format $\left(\mathrm{X}_{3}\right)$} \\
8 & Desain tampilan SIMPEG memiliki layout yang memudahkan & \\
9 & pengguna & Struktur menu dan link dalam tampilan SIMPEG mudah dipahami \\
\hline 10 & SIMPEG sangat mudah digunakan & Ease Of Use $\left(\mathrm{X}_{4}\right)$ \\
11 & SIMPEG mudah diakses darimana saja dan kapan saja & \multirow{2}{*}{ Timeliness $\left(\mathrm{X}_{5}\right)$} \\
\hline 12 & Informasi yang pegawai butuhkan dengan cepat diperoleh melalui \\
13 & SIMPEG & \\
\hline 14 & PIMPEG selalu menampilkan informasi yang terbaru & \\
15 & Pegawai merasa puas dengan keakuratan informasi yang diberikan oleh & \\
16 & SIMPEG & \\
17 & Pegawai merasa puas dengan tampilan yang tersedia pada SIMPEG & User Satisfaction $\left(\mathrm{Y}_{1}\right)$ \\
18 & Pegawai merasa puas dengan ketepatan informasi pada SIMPEG & \\
\hline
\end{tabular}




\begin{tabular}{clc}
\hline No & \multicolumn{1}{c}{ Indikator Konstruk } & Variabel HOT-Fit \\
\hline 19 & Kemudahan dalam menggunakan SIMPEG & \\
20 & Kemudahan dalam mempelajari SIMPEG & Sistem Quality $\left(\mathrm{X}_{6}\right)$ \\
21 & Kecepatan waktu respon SIMPEG & \\
22 & SIMPEG jarang mengalami error & \\
23 & SIMPEG menyediakan fasilitas petunjuk penggunaan & \\
24 & SIMPEG memiliki keamanan sistem yang memadai & \\
\hline 25 & SIMPEG menyajikan isi informasi yang lengkap & \\
26 & Informasi yang diberikan oleh SIMPEG dapat dipertanggungjawabkan & Information Quality $\left(\mathrm{X}_{7}\right)$ \\
27 & Informasi yang ditampilkan oleh SIMPEG relevan & \\
28 & Informasi yang tersaji di SIMPEG mudah dibaca & \\
29 & Penyajian Informasi di SIMPEG terlihat jelas & Service Quality $\left(\mathrm{X}_{8}\right)$ \\
30 & SIMPEG memiliki ketepatan waktu dalam menyajikan informasi & Sistem Use $\left(\mathrm{X}_{9}\right)$ \\
\hline 31 & Organisasi memberikan jaminan kualitas layanan ke pengguna SIMPEG & \\
32 & Organisasi memiliki empati saat membantu pengguna SIMPEG & User Satisfaction $\left(\mathrm{X}_{9}\right)$ \\
\hline 33 & Pengguna SIMPEG memiliki pengetahuan yang cukup & \\
\hline 34 & Pengguna SIMPEG puas terhadap informasi yang ditampilkan SIMPEG & \\
35 & Pengguna SIMPEG puas terhadap fitur yang ada di SIMPEG & \\
36 & Pengguna SIMPEG puas terhadap tampilan SIMPEG & Structure Organization $\left(\mathrm{X}_{11}\right)$ \\
\hline 37 & SIMPEG mampu meningkatkan kinerja organisasi & \\
38 & SIMPEG memiliki pembaharuan perangkat & \\
39 & Adanya dukungan dari organisasi dalam hal pelatihan SIMPEG & \\
40 & SIMPEG memiliki fasilitas yang dibutuhkan organisasi & \\
\hline 41 & Efektivitas dan Efisiensi penggunaan SIMPEG & SIMPEG meningkatkan kualitas organisasi \\
\hline
\end{tabular}

Selanjutnya, uji hipotesis pada penelitian ini adalah uji korelasi peringkat Spearman (spearman rank correlation) untuk menguji hubungan dua variabel yang diteliti menggunakan persamaan (2).

$$
t=\sqrt[r_{s}]{\frac{N-2}{1-r s^{2}}}
$$

Dengan,

$t=$ Tingkat signifikansi ( $\mathrm{t}_{\text {hitung }}$ )

$r s=$ Koefisien korelasi peringkat spearman

$N=$ Banyaknya responden

Kriteria penilaian korelasi yang digunakan untuk mengetahui tingkatan hubungan antara variabel-variabel yang diteliti menggunakan tabel interpretasi nilai $r$ [18], [19] pada Tabel 3.

\begin{tabular}{cc}
\multicolumn{2}{c}{ Tabel 3. Interpretasi penilaian korelasi } \\
\hline Interval Koefisien & Tingkat Hubungan \\
\hline $0.00-0.199$ & Sangat Lemah \\
$0.20-0.399$ & Lemah \\
$0.40-0.599$ & Cukup \\
$0.60-0.799$ & Kuat \\
$0.80-1.000$ & Sangat Kuat \\
\hline
\end{tabular}

\subsection{Model Hipotesis}

Hipotesis didalam sebuah penelitian dapat diartikan sebagai jawaban sementara atas suatu masalah yang masih bersifat praduga karena harus dibuktikan kebenarannya [20], [21]. Hipotesis yang dirancang pada penelitian ini terdiri dari sembilan hipotesis untuk menjelaskan variabel yang mempengaruhi penggunaan SIMPEG. Adapun rancangan hipotesis pada penelitian ini dapat dilihat pada Gambar 1. 


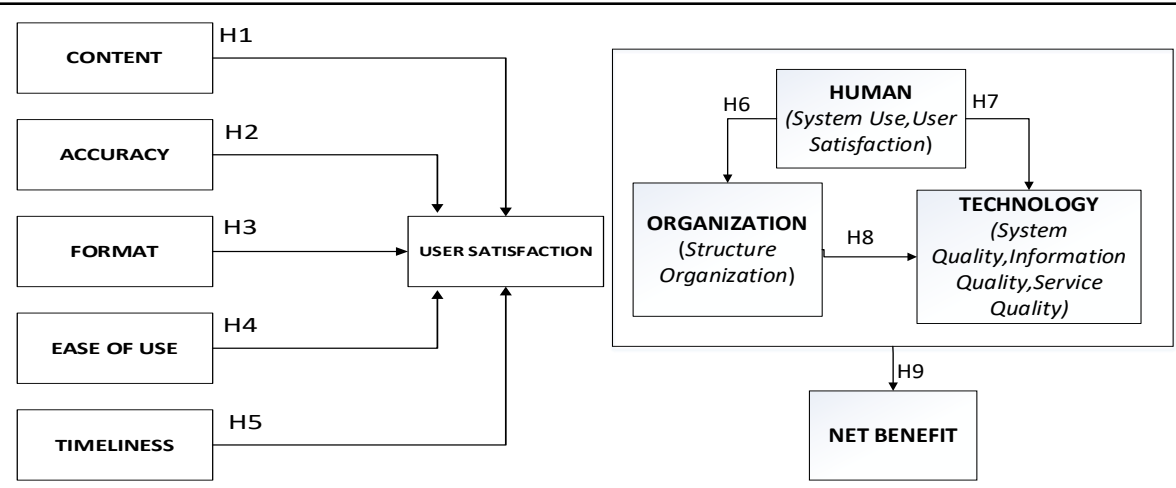

Gambar 1. Model Hipotesis

Hipotesis dalam penelitian ini dijelaskan sebagai berikut:

$\mathrm{H} 1$ : Content (konten) memiliki pengaruh terhadap positif User Satisfaction (kepuasan pengguna).

H2 : Accuracy (keakuratan) memiliki pengaruh positif terhadap User Satisfaction (kepuasan pengguna).

H3 : Format (tampilan) memiliki pengaruh positif terhadap User Satisfaction (kepuasan pengguna).

$\mathrm{H} 4$ : Ease of use (kemudahan penggunaan) memiliki pengaruh positif terhadap User Satisfaction (kepuasan pengguna).

H5 : Timeliness (ketepatan) memiliki pengaruh positif terhadap User Satisfaction (kepuasan pengguna).

H6 : Human (manusia) memiliki pengaruh positif terhadap Organization (organisasi).

H7 : Human (manusia) memiliki pengaruh positif terhadap Technology (teknologi).

H8: Organization (organisasi) memiliki pengaruh positif terhadap Technology (teknologi).

H9: Human (manusia), Organization (organisasi), Technology (teknologi) memiliki pengaruh terhadap Net Benefits (faktor keuntungan).

\section{HASIL DAN PEMBAHASAN}

Pada bab ini akan dijelaskan hasil dan pembahasan dari penelitian yang telah dilakukan.

\subsection{Pengujian Validitas}

Uji validitas pada penelitian ini bertujuan untuk menguji kevalidan item pernyataan pada kuesioner yang telah disebarkan kepada responden. Pengujian validitas pada penelitian ini menggunakan tools SPSS. Adapun dasar pengambilan keputusan pada pengujian validitas adalah berdasarkan rhitung dan rtabel dengan syarat Jika $r_{\text {hitung }}>r_{\text {tabel }}$, maka item pertanyaan dinyatakan valid. Jika $r_{h i t u n g}<r_{\text {tabel}}$, maka item pertanyaan dinyatakan tidak valid. Pada penelitian ini tingkat signifikansi yang digunakan sebesar $5 \%(\alpha=0.05)$ dan $\mathrm{r}_{\text {tabel }}$ sebesar $95 \%(0.2058)$. Tingkat signifikansi yang dipilih memiliki arti bahwa pertanggungjawaban terhadap hasil penelitian yang telah dilakukan apabila terdapat kekeliruan dalam proses penelitian, besarnya tidak lebih dari 5\%. Tabel 4 dan 5 menunjukkan pengujian validitas metode UECS dan HOTFit.

Tabel 4. Hasil uji validitas metode EUCS

\begin{tabular}{|c|c|c|c|c|}
\hline No & Variabel & $r_{\text {tabel }}$ & rhitung & Kriteria \\
\hline \multicolumn{5}{|c|}{ Content $\left(\mathrm{X}_{1}\right)$} \\
\hline 1 & Isi dari informasi SIMPEG sesuai kebutuhan pegawai & 0.2058 & 0.601 & Valid \\
\hline 2 & SIMPEG menampilkan isi informasi yang mudah dipahami & 0.2058 & 0.609 & Valid \\
\hline 3 & SIMPEG menampilkan isi informasi yang mudah dan lengkap & 0.2058 & 0.365 & Valid \\
\hline 4 & $\begin{array}{l}\text { Isi dari informasi di SIMPEG sangat jelas } \\
\qquad \text { Accuracy }\left(\mathrm{X}_{2}\right)\end{array}$ & 0.2058 & 0.524 & Valid \\
\hline 5 & SIMPEG sudah memberikan informasi yang akurat dan benar & 0.2058 & 0.812 & Valid \\
\hline 6 & $\begin{array}{l}\text { SIMPEG selalu selalu menampilkan halaman web yang sesuai bila } \\
\text { pengguna mengklik setiap link di SIMPEG } \\
\qquad \text { Format }\left(\mathrm{X}_{3}\right)\end{array}$ & 0.2058 & 0.897 & Valid \\
\hline 7 & Pengaturan warna dalam desain tampilan SIMPEG sangat menarik & 0.2058 & 0.593 & Valid \\
\hline 8 & Desain tampilan SIMPEG memiliki layout yang memudahkan pengguna & 0.2058 & 0.376 & Valid \\
\hline 9 & $\begin{array}{l}\text { Struktur menu dan link dalam tampilan SIMPEG mudah dipahami } \\
\text { Ease Of Use }\left(\mathrm{X}_{4}\right)\end{array}$ & 0.2058 & 0.460 & Valid \\
\hline 10 & SIMPEG sangat mudah digunakan & 0.2058 & 0.842 & Valid \\
\hline 11 & $\begin{array}{c}\text { SIMPEG mudah diakses darimana saja dan kapan saja } \\
\text { Timeliness }\left(\mathrm{X}_{5}\right)\end{array}$ & 0.2058 & 0.652 & Valid \\
\hline 12 & Informasi yang pegawai butuhkan dengan cepat diperoleh melalui SIMPEG & 0.2058 & 0.706 & Valid \\
\hline 13 & SIMPEG selalu menampilkan informasi yang terbaru & 0.2058 & 0.886 & Valid \\
\hline
\end{tabular}




\begin{tabular}{|c|c|c|c|c|}
\hline No & Variabel & $r_{\text {tabel }}$ & rhitung & Kriteria \\
\hline \multicolumn{5}{|c|}{ Content $\left(\mathrm{X}_{1}\right)$} \\
\hline \multicolumn{5}{|c|}{ User Satisfaction $\left(\mathrm{Y}_{1}\right)$} \\
\hline 14 & Pegawai merasa puas dengan konten pada SIMPEG & 0.2058 & 0.457 & Valid \\
\hline 15 & Pegawai merasa puas dengan keakuratan informasi yang diberikan oleh & & & \\
\hline 15 & SIMPEG & 0.2058 & 0.884 & Valid \\
\hline 16 & Pegawai merasa puas dengan tampilan yang tersedia pada SIMPEG & 0.2058 & 0.419 & Valid \\
\hline 17 & Pegawai merasa puas dengan kemudahan penggunaan SIMPEG & 0.2058 & 0.872 & Valid \\
\hline 18 & Pegawai merasa puas dengan ketepatan informasi pada SIMPEG & 0.2058 & 0.918 & Valid \\
\hline
\end{tabular}

Berdasarkan hasil uji validitas terhadap metode UECS dan HOT-Fit yang terlihat pada Tabel 4 dan 5 menunjukkan bahwa nilai cornbach alpha untuk seluruh variabel dari setiap item pertanyaan lebih besar dari nilai $\mathrm{r}_{\text {tabel }}=0.2058$ sehingga dapat dikatakan bahwa semua variabel valid.

Tabel 5. Hasil uji validitas metode HOT-Fit

\begin{tabular}{|c|c|c|c|c|}
\hline No & Variabel & $r_{\text {tabel }}$ & rhitung & Kriteria \\
\hline \multicolumn{5}{|c|}{ Sistem Quality $\left(\mathrm{X}_{6}\right)$} \\
\hline 1 & Kemudahan dalam menggunakan SIMPEG & 0.2058 & 0.549 & Valid \\
\hline 2 & Kemudahan dalam mempelajari SIMPEG & 0.2058 & 0.482 & Valid \\
\hline 3 & Kecepatan waktu respon SIMPEG & 0.2058 & 0.455 & Valid \\
\hline 4 & SIMPEG jarang mengalami error & 0.2058 & 0.779 & Valid \\
\hline 5 & SIMPEG menyediakan fasilitas petunjuk penggunaan & 0.2058 & 0.593 & Valid \\
\hline 6 & $\begin{array}{l}\text { SIMPEG memiliki keamanan sistem yang memadai } \\
\text { Information Quality }\left(\mathrm{X}_{7}\right)\end{array}$ & 0.2058 & 0.754 & Valid \\
\hline 7 & SIMPEG menyajikan isi informasi yang lengkap & 0.2058 & 0.587 & Valid \\
\hline 8 & Informasi yang diberikan oleh SIMPEG dapat dipertanggungjawabkan & 0.2058 & 0.813 & Valid \\
\hline 9 & Informasi yang ditampilkan oleh SIMPEG relevan & 0.2058 & 0.825 & Valid \\
\hline 10 & Informasi yang tersaji di SIMPEG mudah dibaca & 0.2058 & 0.779 & Valid \\
\hline 11 & Penyajian Informasi di SIMPEG terlihat jelas & 0.2058 & 0.677 & Valid \\
\hline 12 & $\begin{array}{l}\text { SIMPEG memiliki ketepatan waktu dalam menyajikan informasi } \\
\text { Service Quality }\left(\mathrm{X}_{8}\right)\end{array}$ & 0.2058 & 0.791 & Valid \\
\hline 13 & Organisasi memberikan jaminan kualitas layanan ke pengguna SIMPEG & 0.2058 & 0.807 & Valid \\
\hline 14 & $\begin{array}{l}\text { Organisasi memiliki empati saat membantu pengguna SIMPEG } \\
\text { Sistem Use (X) }\end{array}$ & 0.2058 & 0.554 & Valid \\
\hline 15 & $\begin{array}{c}\text { Pengguna SIMPEG memiliki pengetahuan yang cukup } \\
\text { User Satisfaction }\left(\mathrm{X}_{9}\right)\end{array}$ & 0.2058 & 0.842 & Valid \\
\hline 16 & Pengguna SIMPEG puas terhadap informasi yang ditampilkan SIMPEG & 0.2058 & 0.537 & Valid \\
\hline 17 & Pengguna SIMPEG puas terhadap fitur yang ada di SIMPEG & 0.2058 & 0.813 & Valid \\
\hline 18 & $\begin{array}{l}\text { Pengguna SIMPEG puas terhadap tampilan SIMPEG } \\
\text { Structure Organization }\left(\mathrm{X}_{11}\right)\end{array}$ & 0.2058 & 0.398 & Valid \\
\hline 19 & SIMPEG mampu meningkatkan kinerja organisasi & 0.2058 & 0.719 & Valid \\
\hline 20 & SIMPEG memiliki pembaharuan perangkat & 0.2058 & 0.809 & Valid \\
\hline 21 & Adanya dukungan dari organisasi dalam hal pelatihan SIMPEG & 0.2058 & 0.396 & Valid \\
\hline 22 & $\begin{array}{l}\text { SIMPEG memiliki fasilitas yang dibutuhkan organisasi } \\
\text { Net Benefits }\left(\mathrm{Y}_{2}\right)\end{array}$ & 0.2058 & 0.394 & Valid \\
\hline 23 & Efektivitas dan Efisiensi penggunaan SIMPEG & 0.2058 & 0.685 & Valid \\
\hline 24 & SIMPEG meningkatkan kualitas organisasi & 0.2058 & 0.582 & Valid \\
\hline
\end{tabular}

\subsection{Pengujian Reliabilitas}

Uji reliabilitas pada penelitian ini bertujuan untuk menguji konsistensi item pernyataan pada kuesioner yang telah disebarkan kepada responden. Pengujian reliabilitas pada penelitian ini juga menggunakan tools SPSS. Adapun dasar pengambilan keputusan pada pengujian reliabilitas adalah berdasarkan $\mathrm{r}_{\text {tabel }}$ dan nilai cornbach alpha dengan syarat Jika alpha $(\alpha)>\mathrm{r}_{\text {tabel, }}$, maka item pertanyaan dinyatakan reliabel. Jika alpha $(\alpha)<\mathrm{r}_{\text {tabel, }}$, maka item pertanyaan dinyatakan tidak reliabel. Pada penelitian ini nilai cornbach alpha yang digunakan sebesar $5 \%(\alpha=0.05)$ dan $r_{\text {tabel }}$ sebesar $95 \%(0.2058)$. Gambar 2 menampilkan pengujian reliabilitas menggunakan SPSS dan Tabel 6 menunjukkan pengujian reliabilitas dari metode UECS dan HOT-Fit. 


\begin{tabular}{|c|c|c|c|c|}
\hline & $\begin{array}{l}\text { Scale Mean if } \\
\text { Item Deleted }\end{array}$ & $\begin{array}{l}\text { Scale Variance } \\
\text { if Item Deleted }\end{array}$ & $\begin{array}{l}\text { Corrected Item- } \\
\text { Total Correlation }\end{array}$ & $\begin{array}{c}\text { Cronbach's } \\
\text { Alpha if Item } \\
\text { Deleted }\end{array}$ \\
\hline $\mathrm{X} 1$ & 43.79 & 39.747 & .473 & .906 \\
\hline $\mathrm{X} 2$ & 50.60 & 37.146 & .871 & .844 \\
\hline $\mathrm{X} 3$ & 47.02 & 44.113 & .665 & .882 \\
\hline $\mathrm{X} 4$ & 50.78 & 38.014 & .739 & .862 \\
\hline $\mathrm{X} 5$ & 50.46 & 37.575 & .799 & .853 \\
\hline Y1 & 41.32 & 27.349 & .895 & .840 \\
\hline
\end{tabular}

\begin{tabular}{|l|r|r|r|r|}
\hline & & & & Item-Total Statistics \\
& Scale Mean if & Scale Variance & Corrected Item- & Clpha if Item \\
Alem Deleted & if Item Deleted & Total Correlation & Deleted \\
\hline X6 & 58.78 & 40.079 & .771 & .852 \\
X7 & 57.71 & 38.659 & .888 & .824 \\
X8 & 70.67 & 56.194 & .818 & .848 \\
X9 & 73.60 & 66.630 & .339 & .889 \\
X10 & 67.35 & 56.166 & .718 & .854 \\
X11 & 64.22 & 49.756 & .777 & .839 \\
Y2 & 70.62 & 58.272 & .623 & .863 \\
\hline
\end{tabular}

Gambar 2. Uji Reliabilitas SPSS

Berdasarkan hasil uji reliabilitas terhadap metode UECS dan HOT-Fit yang ditampilkan oleh Tabel 6 menunjukkan bahwa nilai cornbach alpha untuk seluruh variabel dari setiap item pertanyaan lebih besar dari nilai $\mathrm{r}_{\text {tabel }}=0.2058$ sehingga dapat dikatakan bahwa semua variabel reliable.

Tabel 6. Hasil uji reliabilitas metode EUCS dan HOT-Fit

\begin{tabular}{ccccc}
\hline Metode & Variabel & rtabel & Alpha $(\alpha)$ & Kriteria \\
\hline \multirow{6}{*}{ EUCS } & $\mathrm{X}_{1}$ & 0.2058 & 0.906 & Reliabel \\
& $\mathrm{X}_{2}$ & 0.2058 & 0.844 & Reliabel \\
& $\mathrm{X}_{3}$ & 0.2058 & 0.882 & Reliabel \\
& $\mathrm{X}_{4}$ & 0.2058 & 0.862 & Reliabel \\
& $\mathrm{X}_{5}$ & 0.2058 & 0.853 & Reliabel \\
& $\mathrm{Y}_{1}$ & 0.2058 & 0.840 & Reliabel \\
\hline \multirow{6}{*}{ HOT-Fit } & $\mathrm{X}_{6}$ & 0.2058 & 0.852 & Reliabel \\
& $\mathrm{X}_{7}$ & 0.2058 & 0.824 & Reliabel \\
& $\mathrm{X}_{8}$ & 0.2058 & 0.848 & Reliabel \\
& $\mathrm{X}_{9}$ & 0.2058 & 0.889 & Reliabel \\
& $\mathrm{X}_{10}$ & 0.2058 & 0.854 & Reliabel \\
& $\mathrm{X}_{11}$ & 0.2058 & 0.839 & Reliabel \\
& $\mathrm{Y}_{2}$ & 0.2058 & 0.863 & Reliabel \\
\hline
\end{tabular}




\subsection{Pengujian Hipotesis}

Pengujian hipotesis pada penelitian ini bertujuan untuk mengetahui korelasi (hubungan) yang terjadi antar variabel. Pengujian hipotesis menggunakan tools SPSS dengan nilai signifikansi sebesar 5\% $(\alpha=0.05)$. Jika nilai signifikansi < 0.05 maka variabel berkorelasi dan hipotesis diterima, namun jika nilai signifikansi $>0.05$ maka variabel tidak berkorelasi dan hipotesis tidak diterima. Lebih lanjut, untuk melihat tingkatan korelasi hubungan antar variabel yang ditunjukkan oleh nilai $r$ (korelasi) dapat menggunakan Tabel 2 yaitu tabel interpretasi penilaian korelasi. Hasil keseluruhan pengujian hipotesis ditampilkan oleh Tabel 7 .

Tabel 7. Hasil pengujian hipotesis

\begin{tabular}{cccc}
\hline Hipotesis & Keterangan & Nilai Korelasi $(\boldsymbol{r})$ & Kategori \\
\hline H1 & Diterima & 0.651 & Kuat \\
H2 & Diterima & 0.770 & Kuat \\
H3 & Diterima & 0.646 & Kuat \\
H4 & Diterima & 0.661 & Kuat \\
H5 & Diterima & 0.663 & Kuat \\
H6 & Diterima & 0.756 & Kuat \\
H7 & Diterima & 0.805 & Sangat Kuat \\
H8 & Diterima & 0.741 & Kuat \\
H9 & Diterima & 0.619 & Kuat \\
\hline
\end{tabular}

Dari hasil pengujian hipotesis yang ditampilkan Tabel 7 terlihat bahwa kesembilan hipotesis diterima dan satu hipotesis yang memiliki kategori sangat kuat. Hipotesis pertama (H1) menyatakan bahwa variabel content (konten) memiliki pengaruh yang kuat sebesar 0.651 terhadap user satisfaction (kepuasaan pengguna), hal ini menandakan bahwa semakin bagus kualitas konten dari SIMPEG dalam menampilkan informasi yang jelas dan akurat serta mudah dipahami maka kepuasan pengguna SIMPEG semakin tinggi. Hipotesis kedua $(\mathrm{H} 2)$ menyatakan bahwa variabel accuracy (keakuratan) memiliki pengaruh yang kuat sebesar 0.770 terhadap user satisfaction (kepuasaan pengguna), dimana semakin tinggi akurasi informasi yang dimiliki oleh SIMPEG maka semakin tinggi juga kepuasan pengguna SIMPEG. Hipotesis ketiga (H3) menyatakan bahwa variabel format (tampilan) memiliki pengaruh kuat terhadap user satisfaction (kepuasaan pengguna) sebesar 0.646, artinya semakin bagus tampilan yang dimiliki serta kemudahan untuk dipahami dalam penggunaan SIMPEG maka pengguna akan merasa bahagia (puas) dalam menggunakan SIMPEG.

Hipotesis keempat (H4) menyatakan bahwa variabel ease of use (kemudahan penggunaan) memiliki pengaruh kuat sebesar 0.661 terhadap user satisfaction (kepuasaan pengguna), korelasi ini menyatakan bahwa kemudahan dalam menggunakan serta mengakses SIMPEG memberikan kepuasan terhadap pengguna SIMPEG. Hipotesis kelima (H5) yaitu variabel timeliness (ketepatan waktu) yang memiliki pengaruh kuat sebesar 0.663 terhadap user satisfaction (kepuasaan pengguna), artinya ketepatan waktu SIMPEG dalam menampilkan informasi yang terbaru memberikan rasa puas terhadap pengguna SIMPEG. Hipotesis keenam (H6) yaitu variabel human (manusia) yang memiliki pengaruh kuat terhadap organization (organisasi) dengan nilai sebesar 0.756 , menunjukkan bahwa adanya dukungan nyata dari organisasi kepada pengguna SIMPEG sehingga membuat penerapan SIMPEG menjadi optimal.

Hipotesis ketujuh (H7) yang menyatakan bahwa variabel human (manusia) memiliki pengaruh terhadap technology (teknologi), menandakan bahwa adanya dukungan yang diberikan oleh organisasi terhadap SIMPEG, memberikan pengaruh positif yang membuat pengguna merasa nyaman dan optimal dalam menggunakan SIMPEG. Hipotesis kedelapan (H8) yaitu variabel organization (organisasi) memiliki pengaruh sangat kuat dengan nilai 0.805 terhadap technology (teknologi), menandakan bahwa adanya pengelolaan dan pemberian fasilitas yang baik dari organisasi terhadap teknologi yang dimiliki membuat penggunaan SIMPEG menjadi optimal. Hipotesis sembilan (H9) menyatakan bahwa ketiga variabel (Human, Organization and Technology) memiliki pengaruh yang kuat sebesar 0.619 terhadap Net Benefits (faktor keuntungan), dimana hal ini menunjukan bahwa manusia, organisasi dan teknologi saling berhubungan dan bekerjasama dengan baik demi terciptanya manfaat dalam penggunaan SIMPEG.

\section{KESIMPULAN}

Berdasarkan penelitian yang telah dilakukan dalam mengevaluasi penerapan SIMPEG, bahwa dari kesembilan hipotesis yang dibentuk, keseluruhan hipotesis diterima dan menunjukkan hasil yang baik. Pengaruh yang paling kuat terdapat pada hubungan manusia terhadap teknologi (SIMPEG), dimana pegawai dapat memanfaatkan teknologi yang diberikan secara optimal. Hal ini menandakan bahwa SIMPEG memiliki teknologi yang handal sehingga animo pengguna dalam menggunakan SIMPEG sangat besar. Lebih lanjut, tingkat hubungan antara manusia, organisasi, teknologi terhadap kebermanfaatan SIMPEG masih kurang maksimal sehingga perlu ditingkatkan seperti menjalin komunikasi yang baik dari organisasi kepada para pengguna SIMPEG, pemberian dukungan dari berbagai pihak dalam penggunaan SIMPEG, dan terus menerus (secara berkelanjutan) melakukan pembaharuan terhadap software maupun hardware pendukung SIMPEG agar kedepannya kebermanfaatan SIMPEG dapat semakin meningkat dan dirasakan secara menyeluruh. 


\section{DAFTAR PUSTAKA}

[1] H. Haerudin, "Evaluasi Sistem Informasi Untuk Mengetahui Tingkat Kepuasan Pengguna Www. My. Unpam. Ac. Id Dengan Menggunakan Metode Eucs Dan Pieces," J. Inform. Univ. Pamulang, vol. 2, no. 4, pp. 174-178, 2017.

[2] N. E. Rozanda and A. Masriana, "Perbandingan Metode Hot Fit dan Tam dalam Mengevaluasi Penerapan Sistem Informasi Manajemen Kepegawaian (SIMPEG) (Studi Kasus : Pengadilan Tata Usaha Negara Pekanbaru)," Semin. Nas. Teknol. Informasi, Komun. dan Ind. 9, 2017.

[3] R. Anggara, C. W. Budiyanto, and P. Hatta, "Comparison between TAM, EUCS, TTF analysis to evaluate user acceptance for conference management system," 2019, doi: 10.1063/1.5139737.

[4] E. Budiman, N. Puspitasari, M. Taruk, and E. Maria, "Webqual 4.0 and ISO/IEC 9126 Method for website quality evaluation of higher education," in Proceedings, 2020, pp. 11-18.

[5] E. Budiman, N. Puspitasari, Haerullah, M. Jamil, M. Wati, and A. Saudek, "Evaluation of the bioinformatics resource portal,” 2018, doi: 10.1109/ICITISEE.2018.8720973.

[6] P. D. Abda'u, W. W. Winarno, and H. Henderi, "Evaluasi Penerapan SIMRS Menggunakan Metode HOTFit di RSUD dr. Soedirman Kebumen," INTENSIF J. Ilm. Penelit. dan Penerapan Teknol. Sist. Inf., 2018, doi: 10.29407/intensif.v2i1.11817.

[7] M. B. Firdaus, N. Puspitasari, E. Budiman, J. A. Widians, and N. Bayti, "Analysis of the effect of quality mulawarman university language center websites on user satisfaction using the webqual 4.0 method," 2019, doi: 10.1109/ICAITI48442.2019.8982143.

[8] A. S. Damayanti, Y. T. Mursityo, and A. D. Herlambang, "Evaluasi Kepuasan Pengguna Aplikasi Tapp Market Menggunakan Metode EUCS (End User Computing Satisfaction)," J. Pengemb. Teknol. Inf. dan Ilmu Komput. e-ISSN, vol. 2548, p. 964X, 2018.

[9] A. R. Darwi and E. Efrizon, "ANALISIS KEPUASAN PENGGUNA E-LEARNING SEBAGAI PENDUKUNG AKTIVITAS PEMBELAJARAN MENGGUNAKAN METODE EUCS," VoteTEKNIKA J. Vocat. Tek. Elektron. dan Inform., vol. 7, no. 1, pp. 25-31, 2019.

[10] Usman Ependi1, Rusmin Syafari, and Pitria Maharani, "END USER COMPUTING SATISFACTION ON WEBSITE PERPUSTAKAAN DAERAH SUMATERA SELATAN," J. Teknol. Inf. Univ. Lambung Mangkurat, vol. 3, no. 1, pp. 35-46, 2018, doi: 10.20527/jtiulm.v3i1.26.

[11] N. Puspitasari, R. Lestari, M. Taruk, and E. Maria, "Website Testing Analysis Using PIECES and EUCS Method," 2019, doi: 10.1109/ICEEIE47180.2019.8981417.

[12] R. Munap, S. N. B. Ahmad, S. A. Hamid, and M. F. B. M. Talib Beg, "The Influence of End User Computing System (EUCS) on User Satisfaction: The Case of a Logistic and Courier Service Company," Int. J. Soc. Sci. Humanit. Invent., 2018, doi: 10.18535/ijsshi/v5i12.03.

[13] Y. Nurdiansyah, E. P. A. Wulandari, and D. A. R. Wulandari, "Analisis Faktor Kepuasan Pengguna Layanan Website SKCK Online Menggunakan Metode End User Computing Satisfaction (EUCS)," INFORMAL Informatics J., vol. 5, no. 2, pp. 72-76, 2020, doi: 10.19184/isj.v5i2.18669.

[14] D. Nurmaini and C. Ismiati, "Analisis Tingkat Kepuasan Pengguna Online Public Access Catalog (OPAC) dengan Metode EUCS,” J. Rekayasa dan Manaj. Sist. Inf., 2016.

[15] W. J. Doll and G. Torkzadeh, "The measurement of end-user computing satisfaction,” MIS Q., pp. 259274, 1988.

[16] A. Prasetyowati and R. Kushartanti, "Pengaruh Faktor Hot (Human, Organisasi, Dan Teknologi) Terhadap Kepuasan Pengguna Sistem Informasi Primary Care Di Wilayah Kota Semarang," J. Manaj. Inf. Kesehat. Indones., 2018, doi: 10.33560/.v6i1.188.

[17] A. Alfina and R. Irfan, "Analysis of E-learning implementation using Human Organization Technology approach (HOT) Fit Models,” 2020, doi: 10.1088/1742-6596/1456/1/012058.

[18] Riduwan, Dasar Dasar Statistika. 2010.

[19] R. Fauziah, R. Maya, and A. Y. Fitrianna, "HUBUNGAN SELF CONFIDENCE TERHADAP KEMAMPUAN PEMECAHAN MASALAH MATEMATIS SISWA SMP," JPMI (Jurnal Pembelajaran Mat. Inov., 2018, doi: 10.22460/jpmi.v1i5.p881-886.

[20] N. Puspitasari, M. B. Firdaus, C. A. Haris, and H. J. Setyadi, “An application of the UTAUT model for 
Jurnal SITECH, Vol 4, No 1, Juni 2021

$P-I S S N$ : 2615-8531, E-ISSN : 2622-2973

analysis of adoption of integrated license service information system," in Procedia Computer Science, 2019, vol. 161, doi: 10.1016/j.procs.2019.11.099.

[21] Sugiyono, Memahami Penelitian Kualitatif. Bandung: Alfabeta, 2016. 